\title{
Spermine either delays or promotes cell death in Nicotiana tabacum L. corolla depending on the floral developmental stage and affects the distribution of transglutaminase
}

This is the peer reviewed version of the following article:

Original:

Cai, G., Della Mea, M., Faleri, C., Fattorini, L., Aloisi, I., Serafini Fracassini, D., et al. (2015). Spermine either delays or promotes cell death in Nicotiana tabacum L. corolla depending on the floral developmental stage and affects the distribution of transglutaminase. PLANT SCIENCE, 241, 11-22 [10.1016/j.plantsci.2015.09.023].

Availability:

This version is availablehttp://hdl.handle.net/11365/982225

since 2015-12-02T09:29:33Z

Published:

DOI:10.1016/j.plantsci.2015.09.023

Terms of use:

Open Access

The terms and conditions for the reuse of this version of the manuscript are specified in the publishing policy. Works made available under a Creative Commons license can be used according to the terms and conditions of said license.

For all terms of use and more information see the publisher's website.

(Article begins on next page) 


\section{Accepted Manuscript}

Title: Spermine either delays or promotes cell death in Nicotiana tabacum L. corolla depending on the floral developmental stage and affects the distribution of transglutaminase

Author: Giampiero Cai Massimiliano Della Mea Claudia

Faleri Laura Fattorini Iris Aloisi Donatella Serafini-Fracassini Stefano Del Duca

PII: S0168-9452(15)30080-7

DOI: http://dx.doi.org/doi:10.1016/j.plantsci.2015.09.023

Reference: PSL 9302

To appear in: $\quad$ Plant Science

Received date: $\quad$ 8-7-2015

Revised date: $\quad 1-9-2015$

Accepted date: $\quad$ 24-9-2015

Please cite this article as: Giampiero Cai, Massimiliano Della Mea, Claudia Faleri, Laura Fattorini, Iris Aloisi, Donatella Serafini-Fracassini, Stefano Del Duca, Spermine either delays or promotes cell death in Nicotiana tabacum L.corolla depending on the floral developmental stage and affects the distribution of transglutaminase, Plant Science http://dx.doi.org/10.1016/j.plantsci.2015.09.023

This is a PDF file of an unedited manuscript that has been accepted for publication. As a service to our customers we are providing this early version of the manuscript. The manuscript will undergo copyediting, typesetting, and review of the resulting proof before it is published in its final form. Please note that during the production process errors may be discovered which could affect the content, and all legal disclaimers that apply to the journal pertain. 


\section{Spermine either delays or promotes cell death in Nicotiana tabacum L. corolla depending on the floral developmental stage and affects the distribution of transglutaminase}

Giampiero CAI ${ }^{1}$, Massimiliano DELLA MEA ${ }^{2}$, Claudia FALERI ${ }^{1}$, Laura FATTORINI ${ }^{3}$, Iris ALOISI $^{2}$, Donatella SERAFINI-FRACASSINI ${ }^{2}$ and Stefano DEL DUCA ${ }^{2} *$

e-mails: $\quad$ cai@unisi.it; $\quad$ massimiliano.dellamea@unibo.it, $\quad$ faleric@unisi.it, laura.fattorini@uniroma1.it, donatella.serafini@unibo.it, stefano.delduca@unibo.it

${ }^{1}$ Dipartimento di Scienze della Vita, Università di Siena, 53100 Siena, Italia, ${ }^{2}$ Dipartimento di Scienze Biologiche, Geologiche e Ambientali, Università degli Studi di Bologna, 40126, Bologna, Italia, ${ }^{3}$ Dipartimento di Biologia Ambientale, Sapienza Università di Roma, I-00185, Italia

* Corresponding author: Stefano Del Duca, Dipartimento di Scienze Biologiche, Geologiche e Ambientali. Università di Bologna, Via Irnerio 42, 40126 Bologna, Italy. Phone: +39-0512091292; Fax: +39051242576. E-mail: stefano.delduca@unibo.it

Footnote: Both authors Giampiero Cai and Massimiliano Della Mea contributed equally to this work.

Highlights

- Spermine (SM) modulates developmentally related programmed cell death (dPCD) in the corolla of $N$. tabacum according to the developmental stage.

- SM counteracts dPCD only within a short window of corolla development.

- Parenchyma cells are the most SM-responsive and undergo deep morphological alterations after SM treatment.

- SM deeply alters the distribution of the polyamine-conjugating enzyme transglutaminase, that accumulates in parenchyma cells. 


\begin{abstract}
The role of spermine (SM) was studied to verify if SM supplied to Nicotiana tabacum flower can modulate programmed cell death (PCD) of the corolla. SM has strong effects on the development and senescence of excised flowers despite its low physiological levels. The timing and duration of SM treatment is a key factor; SM counteracted PCD (verified by morphological observations, pigment contents and DNA laddering) only in the narrow developmental window of corolla expansion. Before and after, SM promotes PCD. SM exerts its pro-survival role by delaying fresh weight loss, by inhibiting reduction of pigments and finally by preventing DNA degradation. Moreover, SM deeply alters the distribution of the PA-conjugating enzyme transglutaminase (TGase). TGase is present in the epidermis during development, but it sprays also in the cell walls of inner parenchyma at senescence. After SM treatment, parenchyma cells accumulate TGase, increase in size and their cell walls do not undergo stiffening contrarily to control cells. The subcellular localization of TGase has been validated by biolistic-transformation of onion epidermal cells.
\end{abstract}

Results indicated that SM is a critical factor in the senescence of Nicotiana tabacum corolla by controlling biochemical and morphological parameters; the lasts are probably interconnected with the action of TGase.

\title{
KEYWORDS
}

Spermine, Nicotiana tabacum corolla, transglutaminase, cell wall, development, programmed cell death.

ABBREVIATIONS: programmed cell death (PCD), developmental cell death (DCD), polyamines (PAs), putrescine (PU), spermidine (SD), spermine (SM), transglutaminase (TGase), abscission zone (AZ). 


\section{1- INTRODUCTION}

Aliphatic polyamines (PAs), putrescine (PU), spermidine (SD) and spermine (SM) are growth substances present in all living organisms that, directly or indirectly interacting with multiple hormonal pathways, are involved in development [1,2]. In reproductive and vegetative plant organs, various parts undergo developmentally regulated programmed cell death (dPCD) [3], a physiological type of programmed cell death (PCD) linked to growth and differentiation that is considered, together with senescence, the last part of development [4,5]. Petal senescence is an active, highly regulated and complex process, controlled by growth factors and hormones, such as ethylene, cytokinins, abscisic acid and polyamines (PAs) [6,7,8]. In plants, many reports have suggested that PAs allow a prolonged survival of excised organs although, like in animals, there are some contradictory data $[9,10,11,12,13,14,15,16,17,18]$.

When the corolla of Nicotiana tabacum enters senescence it becomes acropetally rigid/papyraceous and dies, remaining initially attached to the thalamus then finally falls off. As it is histologically relatively simple, several morpho-functional parameters have been easily established to characterize the different stages of corolla development in tobacco [14]. Proteases are active only during a short period coinciding with the appearance of DNA-laddering, nuclear blebbing, rupture of the tonoplast, chloroplast degradation; in the meantime cell walls of the parenchyma lignify and suberize. Morphological signs of senescence begin in the proximal basal region of the corolla, where the abscission zone (AZ) begins to differentiate, causing an interruption of sap transport so that the entire corolla dehydrates and dies $[4,5,19]$.

Changes of cell morphology related to PCD have been observed in some plant models; i.e. in abscission and dehiscence of anthers the differentiation of specialized margin cell types, followed by cell wall remodelling cell-cell separation processes and deposition of ligno-cellulosic secondary thickening have been observed [19,20].

In tobacco flowers, the initially homogeneous corolla cells are affected in succession by an acropetal program of development and cell death. PA supply to excised flowers slightly delays senescence and dPCD in $N$. tabacum petals with SM being the most efficient; however, the mechanism by which PAs affect plant cell death has not yet been sufficiently clarified as above reported $[10,12]$. We cannot exclude the possibility that PAs also exert their roles in dPCD by the activity of transglutaminase (TGase, R-glutaminylpeptide-amine $\gamma$-glutamyltransferase; E.C. 2.3.2.13), an enzyme able to covalently bind PAs to proteins. TGase is a widespread $\mathrm{Ca}^{2+}$ dependent enzyme and catalyzes PA binding to both structural and enzymatic proteins [21]. TGase catalyzes the formation of cross-links (between a glutamyl residue and a protein lysyl residue or a PA) within the same or between different proteins; for the feature to cross-link proteins TGase has also been called a biological glue [21]. PAs act as physiological substrates of TGase: their terminal 
amino-group binds one or two protein glutamyl residues giving rise to mono-( $\gamma$-glutamyl)-PAs and bis-( $\gamma$-glutamyl)-PAs, respectively. In the latter case, the TGase forms intra- and/or inter-molecular bridges between specific proteins of extracellular matrix, cytoskeleton or photosystems often forming high molecular mass structures that are much less sensitive to proteases and thus more stable $[21,22,23]$. To date, three TGase genes have been described in plants (reviewed by [24]). One gene codes for the Arabidopsis AtPng1 protein (TAIR locus AT5G49570) displaying a transamidase activity, similar to those of animal TGases.

The AtPngl sequence and the antibody specific for AtPng1p have been used for the present research. In animals, TGases are involved in the regulation of cell growth and differentiation [21] and exert pro- or anti-apoptotic roles [25]. In plants, studies have focused on the involvement of TGases in different types of PCD, namely the gametophytic self-incompatibility [26], the hypersensitive response to pathogens [27], and leaf and flower senescence and death [5,10,13,14]. In the corolla of $N$. tabacum, an acropetal increase in the activity of TGase in particular in chloroplast and cell wall fractions preceded the parallel wave of dPCD [5]. A confirmation of this result has been obtained in dark-induced senescence of barley leaves where TGase mRNA level increased along senescence stages [28]. TGase was suggested to exert a possible structural role in the cell wall [29] which however, needs to be better explored.

The present research aims to study the effects of exogenously supplied SM to excised flowers by analyzing different morpho-functional parameters in the cells of $N$. tabacum corolla, in order to clarify if SM acts as pro-survival or PCD-promoting factor. Moreover, the distribution of TGase was monitored in different tissues of the corolla in relation to both the onset of senescence and the SM-treatment. The enzyme localization was comparatively immuno-detected in corollas of nonexcised (in planta) and of excised flowers treated/untreated with SM. The effect of the duration/concentration/transport of supplied SM on development/senescence/death of the corolla in flowers excised at different stages was also evaluated by measuring pigment and protein contents, DNA-laddering, TGase localization. Results indicated that SM can have opposite effects according to the flower developmental stage; it has been observed that developmental stage of the corolla is a key factor for the activity of SM as pro-survival and that SM counteracts senescence by affecting several biochemical and morphological parameters and by affecting TGase localization and activity.

\section{2- MATERIAL AND METHODS}

\section{1- Sampling of flower corolla on the plant}

Plants of N. tabacum L. cv Samsun were grown in the Botanical Garden of the University of

Bologna (Italy) in a growth chamber at a fixed temperature of $25^{\circ} \mathrm{C}\left(12 \mathrm{~h}\right.$ photoperiod at $10^{15}$ quanta 
$\mathrm{cm}^{-2} \mathrm{~s}^{-1}$ ). The corolla lifespan was divided into ten stages [5] identified by the fresh and dry weights measured in the entire corolla and in three sections of the corolla cut transversely into proximal (P), medial (M), and distal (D) portions (Supplementary Information Fig. S1). The stages were also identified based on corolla size, shape, and colour using a Zeiss Stemi SV6 (8-50X) binocular stereoscope. In some experiments, flowers were used at an early stage, pre-1, in which the corolla is still closed, light green and emerging from the calyx to $1.5-2 \mathrm{~cm}$.

\section{2- Determination of the efficiency of water transport and SM uptake in excised flowers}

As a preliminary trial, the efficiency of the water transport of detached flowers was verified by immersing pedicels in a methyl green dye solution. The pedicels were immersed in a solution of SM $(5,25$ or $50 \mathrm{mM})$ for 1,3 and $24 \mathrm{~h}$; the flowers were then transferred to sterilized water containing nano silver particles $(1 \%)$. Alternatively, pedicels were left continuously in SM solution up to the end of the experiment. In order to assess the uptake of SM, $0.2 \mathrm{mM}\left[{ }^{14} \mathrm{C}\right] \mathrm{SM}$ was added as a tracer; the total concentration of SM or its radioactive derivatives in the corolla extract was calculated based on the ratio labelled/unlabelled SM.

\section{3- Pigment extraction and quantification by absorbance measurement.}

Pigments were extracted and their content was determined as described in[14]. Briefly, pigments were extracted by soaking petals in $3 \mathrm{ml}$ methanol-HCl $1 \%$ for $1 \mathrm{~h}$. Anthocyanin content was determined on the clarified supernatant by absorbance measurement according to the formula: $\mathrm{A}_{530}-0.25 \times \mathrm{A}_{657}$. $\mathrm{A}_{657}$ was used to evaluate chlorophyll content as phaeophytin.

\section{4- DNA fragmentation}

Whole corollas (100 mg) were homogenised in liquid nitrogen using a mortar and pestle. Extraction of DNA was performed using the Qiagen Dneasy Plant Minikit according to the manufacturer instructions.

\section{5- Protein content determination}

Whole corollas were homogenized in 1:2 (w/v) $50 \mathrm{mM}$ Tris-HCl, pH 8, containing $2 \mathrm{mM}$ dithiothreitol (DTT), $10 \mathrm{mg} / \mathrm{mL}$ pepstatin, $0.5 \mathrm{mg} / \mathrm{mL}$ leupeptin, $1 \mathrm{mM}$ phenylmethylsulfonyl fluoride (PMSF), 0.1\% Triton X-100 and then centrifuged for $10 \mathrm{~min}$ at $1500 \mathrm{~g}$ and the pellet discarded All steps were performed at $4^{\circ} \mathrm{C}$. Protein determination was performed with the Lowry method [30] on the supernatant using bovine serum albumin as standard.

\section{6- Polyamine determination}

Corollas, extensively washed and homogenized in 3 volumes of cold $5 \%$ (w/v) TCA, were centrifuged for $10 \mathrm{~min}$ at $14000 \mathrm{~g}$, and the free, TCA-soluble and insoluble PAs (the latter two by acid hydrolysis) were dansylated and separated by HPLC [31].

\section{7- Immunolocalization of TGase}


Petals of corollas were cut longitudinally to obtain thin sections along the main axis of the flowers. Smaller sections were then cut transversely at low temperature following the curvature of the corolla and immediately dipped into fixative $(0.1 \%$ glutaraldehyde, $2 \%$ paraformaldehyde, $50 \mathrm{mM}$ Pipes pH 6.8, $100 \mathrm{mM}$ EGTA, $50 \mathrm{mM} \mathrm{MgSO}_{4}, 0.05 \%$ Tween-80). To check the distribution of TGase after treatment with SM for $3 \mathrm{~h}$, samples were let in water for $69 \mathrm{~h}$ before fixation. The protocol for immuno-localization of proteins in tissue sections was according to [32]. Briefly, after dehydration on ice with a gradient of absolute ethanol from 10 to $100 \%$, samples were embedded in Technovit 8100 resin (Heraeus Kulzer) at $4^{\circ} \mathrm{C}$ and let to polymerize at $4^{\circ} \mathrm{C}$ for $3 \mathrm{~h}$. Sections of $2-3$ $\mu \mathrm{m}$ were placed on drops of water and dried at low temperature. Thin sections were obtained with an LKB Nova ultramicrotome. They were immersed in 100\% acetone for $20 \mathrm{~min}$ and rehydrated in PBS. Sections were blocked for $30 \mathrm{~min}$ in the blocking solution (3\% BSA in PBS). The primary anti-TGase antibody (AtPng1p) [33] was diluted 1:50 and incubated overnight at $4^{\circ} \mathrm{C}$. The secondary antibody was Alexa Fluor 488-conjugated goat anti-chicken diluted 1:50 and incubated for $1-2 \mathrm{~h}$ at $37^{\circ} \mathrm{C}$. Images were captured with a Zeiss Axio Imager fluorescence microscope equipped with Apotome module, a 63X objective and an MRm AxioCam video camera; we used the AxioVision software and images were saved as ZVI files.

The cuticle was stained by $0.01 \%$ Auramine $\mathrm{O}$ in $50 \mathrm{mM}$ Tris- $\mathrm{HCl} \mathrm{pH} 7.2$ (5 min). ZVI files were directly imported into ImageJ (http://rsb.info.nih.gov/ij) and the fluorescence intensity was measured in $50 \times 50 \mu \mathrm{m}$ areas starting from the epidermis and going towards the internal parenchyma cells of at least 10 different sections; we used the Measure Tool of ImageJ software. The fluorescence value was subtracted from the background to normalize the data.

\section{8- In situ TGase activity}

The enzymatic activity was visualized by incubating epidermal cells for 30 min with His $_{6}-\mathrm{Xpress}_{-}$ GFP at different concentrations (from 0.25 to $50 \mu \mathrm{g} \cdot \mathrm{ml}^{-1}$ ); His ${ }_{6}$-Xpress-GFP is a specific glutamine- and lysine-rich fluorescent substrate for ECM mammalian TGase modified as reported previously [34]. Fluorescence was observed at the Zeiss Axio Imager optical microscope equipped with a Zeiss UV-H $436 \mathrm{~nm}$ filter (BP436/10, FT 460, LP 470) and compared to the autofluorescence in the untreated control.

\section{9- Transient onion transformation with TGase and plasmolysis}

Single layers of epidermal cells of onion cataphylls were spread over a Petri dish containing MS culture medium (20 g/l sucrose, $0.5 \mathrm{~g} / 1 \mathrm{MES}, 2 \mathrm{~g} / \mathrm{l}$ gelrite, $\mathrm{pH} 5.8$ ) or $20 \mathrm{mM}$ piperazine-N,N'-bis (2-ethane-sulphonic acid)(PIPES)-KOH ( $\mathrm{pH}$ 7.0) [35]. Different $\mathrm{pHs}$ were tested because the enzyme is active in a range between 6 and 8.7 and because GFP fluorescence being pH-dependent, 
can be faint at low pH. Microcarriers (30 mg, $1.0 \mu \mathrm{m}$ Gold, BIO-RAD) were mixed with $1 \mathrm{ml}$ of $70 \%$ cold ethanol, vortexed for 3-5 min at room temperature and settled for $15 \mathrm{~min}$. After pelleting by spinning for $5 \mathrm{sec}$ in a microfuge, microcarriers were resuspended in $1 \mathrm{ml}$ DEPC water and washed three times. After adding $500 \mu \mathrm{l}$ of $50 \%$ glycerol, aliquots of microcarriers were sonicated for 2 min and then, while vortexing, they were added with $10-\mu 1$ plasmid DNA. The full coding sequence of AtPng1 [33] was cloned in pCAMBIA1302 vector under the control of a CaMV 35S promoter and fused in the 3' region with the GFP. Onion cells were bombarded at 900 or 1100 psi with $5 \mu \mathrm{g}$ of DNA plasmids for expression of fusion protein, or GFP alone as control using a biolistic PSD-1000/He particle delivery system (Bio-Rad, Hercules, CA, USA). Bombarded samples were incubated for $24-60 \mathrm{~h}$ at $25^{\circ} \mathrm{C}$ in the dark at 5.8 and $7.0 \mathrm{pH}$ values. Plasmolysis experiments were performed by adding $0.8 \mathrm{M}$ mannitol for $15 \mathrm{~min}$. Samples were observed with the Zeiss Axio Imager microscope.

All chemicals, unless specified, were purchased from Sigma, Aldrich (Milano, Italy).

\subsection{0- Statistical analysis}

Each determination was repeated at least three times and the experiments were repeated at least twice. Differences between sample sets were determined by analysis of variance (two-way and oneway ANOVA, with a threshold $P$-value of 0.05 ) followed by Tukey's post-test using GraphPad Prism.

\section{3- RESULTS}

\section{1- Characteristics of the corolla in planta during development and senescence}

\subsection{1- Abscission zone and transport efficiency}

At stage 4-5, the basal section of the corolla had already undergone a localized cell death at the AZ, as previously observed [5]. The brown ring of AZ was at first incomplete but soon occupied the entire circumference of the corolla (Fig. 1). To evaluate the stage at which the vascular bundles ceased to be active, transport efficiency along the flower was evaluated by immersing the pedicel in methyl green dye. Results showed that transport was very efficient during early stages, whereas by stage 5, not all the bundles showed transport and at stage 6-7 the transport had ceased (Fig. 1). Consequently, the experiments with exogenous SM were restricted to stages 1-6.

\subsection{2- Polyamine content}

Before supplying exogenous PAs, the PU, SD and SM contents of the whole corolla were analyzed in both the soluble (free and bound forms) and in the insoluble forms at stages 1-8. The analysis 
showed a prevalence of PU and SD content versus SM in all three fractions (Fig. 2) and SD was significantly higher than PU only in the insoluble fraction (Fig. 2C). Free PA content decreased significantly from stage 2-3 to stage 5 and then remained constant (Fig. 2A). Both TCA-soluble bound PU and SD peaked at stage 5, and then decreased; however, both maintained a relatively high level until the final stage (Fig. 2B). Among the insoluble forms, SD tends to decrease with time, but also PU, after a peak at stage 4, decreased. Both PAs remained stable at later stages, while soluble and insoluble bound SM was always present in traces (Fig. 2B, C).

\subsection{3- Localization and function of TGase}

The presence of TGase was checked by immunolocalization at full anthesis (stage 4) and at the onset of senescence (stage 6) (Fig. 3A, B). At stage 4, the antibody reacted almost exclusively in the cell walls of the entire epidermal layer especially the adaxial one and more intensely in its outer cell wall and papillae (Fig. 3A a $a_{1}$, b, c, d; Fig. S2). This intense fluorescence co-localized with cutin stain; unlike the cuticle that was present only on the external cell wall of epidermal cells (Fig. 3A $\mathrm{a}_{2}$ ), TGase was also immunolocalized all along other cell borders (e.g. the cell wall) and, to a lesser extent, inside cells (therefore as a cytosolic factor or in association with endomembranes). At stage 6 (Fig. 3B), fluorescence was intense in the epidermal and subepidermal layers on the abaxial and, more prominently, on the adaxial side of the corolla; cuticle staining was similar to that observed at stage 4 (Fig. 3B $\mathrm{a}_{2}$ ). Unlike the inner parenchyma at stage 4, which did not show any fluorescent signal (Fig. 3A d, e), TGase labelling was widely distributed in the inner part of the petal mesophyll (50\% intensity of the epidermal fluorescence) (Fig. 3B d), which appeared homogeneous with regularly shaped cells and without intercellular spaces (stage 6 in Fig. 3B e). The immunofluorescence was mainly distributed in straight cell walls (Fig. 3B d, e); the middle lamella was unstained.

To verify if TGase was active, the epidermis of the senescing corolla was incubated with the recombinant protein His $_{6}$-Xpress-GFP, the specific TGase fluorescent substrate. In this condition, the normal autofluorescence of the cell wall of untreated control (Fig. 4A a) assumed a yellowing staining (Fig. 4A b). This might depend on the binding of His $_{6}$-Xpress-GFP, catalyzed by endogenous TGase, to cytoplasmic or cell wall targets, as suggested by its persistence after extensive washing.

To go more in depth in the possible localization of TGase, an experiment of transformation was performed by a well-established biolistic system. As shown in Fig. 4B, onion epidermal cells were bombarded with a construct of the Arabidopsis TGase fused to GFP (GFP + AtPngl sequence) and with GFP alone as a control. After $24 \mathrm{~h}$ of incubation of transformed onion cells under routine experimental conditions ( $\mathrm{pH}$ 5.8), GFP diffused in the nucleus, cytoplasm as well as at the cell periphery (Fig. 4B a). The cells transformed with Arabidopsis TGase had a similar behaviour to 
GFP control, but fluorescent signal was more intense at cell periphery, possibly in the cell wall (Fig. $4 \mathrm{~B} \mathrm{~b})$.

TGase has an optimum of extracellular activity at $\mathrm{pH} 6.5$ and an intracellular one at a more basic $\mathrm{pH}[33,36]$. Experiments were thus repeated at $\mathrm{pH} 7$ to verify if TGase was active and bound to a natural substrate, also because GFP fluorescence is weak at low $\mathrm{pH}$ [37].

After $24 \mathrm{~h}$ of incubation in these conditions, the panorama was very different. While GFP appeared less widespread in the cytoplasm (Fig. 4B c), but similar to that observed in Fig. 4B a, the expression and activity of TGase were revealed by the presence of fluorescent spots in the cell wall and in the cytoplasm (Fig. 4B d). In the cytoplasm, organelles of about 3-4 $\mu \mathrm{m}$ (inset in Fig. 4B d) and large membranes (Fig. 4D a, arrows) were decorated by small fluorescent spots.

To verify if TGase was located in the cell walls and plasma membrane, an experiment of plasmolysis was performed at both pHs (Fig. 4C and D). In either GFP controls at pH 5.8 (not shown) and pH 7 (Fig. 4C b) or after bombardment with GFP + AtPngl at pH 5.8 (Fig. 4C a), the cells were similar and underwent plasmolysis $(p)$. Moreover, a continuous fluorescence signal outside the plasmalemma seemed to mark the cell wall (Fig. $4 \mathrm{C} \mathrm{a}, \mathrm{b}$ ). By contrast, at $\mathrm{pH} 7$, only in the sample treated with GFP + AtPngl the fluorescence signal was clearly visible in cell wall (Fig. 4C c, detail in $\mathrm{c}_{1}$ ) and inside the cell as membrane/vesicle-like structures (Fig. 4C c and 4D a); several cells were not plasmolyzed ( $n p)$, while other cells were ( $p$ ) (Fig. 4C c, and D b), suggesting that $n p$ cells only were transformed and able to express the active construct. Moreover, the $n p$ cells showed an intense spotted fluorescence at the cell wall and immediately outside in the adjacent cell. This occurred whether or not adjacent cells were plasmolyzed, as shown in the cell wall between two $n p$ cells (Fig. 4D b) and between a $n p$ and a $p$ cell (Fig. 4D c). In addition, adjacent spots were always separated by a negative layer, possibly corresponding to the middle lamella (Fig. $4 \mathrm{C}_{1}$ and 4D c, arrows).

\section{2- Effect of exogenous SM on excised flowers}

\subsection{1- Morphology of the corolla}

The effect of SM on the development and senescence of excised flowers was studied from stage pre-1 to stage 7 by varying the concentration $(1-50 \mathrm{mM})$ and duration $(1,3,72,96$ or $120 \mathrm{~h})$ of the treatment as well as the timing of the application. The most representative data of flowers treated with SM are reported in Fig. 5. Development of flowers excised at stage 1 slowed down after $3 \mathrm{~h}$ of treatment with $25 \mathrm{mM} \mathrm{SM}$ (Fig. 5A) and even more at $50 \mathrm{mM}$ (not shown). In the latter case, corolla abscission was absent at $72 \mathrm{~h}$ whereas it occurred in controls (Fig. 5A a). Stages 2-4 were the most positively responsive in terms of delayed senescence. When untreated, flowers excised at stages (2-4) began to decay after $72 \mathrm{~h}$, whereas $25 \mathrm{mM}$ SM-treated flowers maintained an expanded 
corolla for longer periods (even until $96 \mathrm{~h}$ ); the treatment delayed senescence without causing any tissue damage (Fig. 5A b). The stage 5 was poorly responsive; by contrast, at stage 6, SM enhanced senescence, an effect already visible after 48 h (Fig. 5A c, d). Fig. 5B shows stage 2-3-excised flowers at $96 \mathrm{~h}$ after different periods of $25 \mathrm{mM} \mathrm{SM}$ treatments. The SM treatment for $1-3 \mathrm{~h}$ caused the greatest expansion and "rejuvenation" effect, as shown by the corolla pink colour, shape and the absence of the AZ (not shown), whereas treatment for $96 \mathrm{~h}$ caused the corolla to wilt completely. The diameters of the cylindrical part of the corolla tube of the same flowers, measured up to $120 \mathrm{~h}$, showed a progressive decrease in all treatments, in in planta controls and in water-treated excised controls (Fig. 5C). After $120 \mathrm{~h}$, the in planta controls and water-treated controls were significantly different from the $3 \mathrm{~h} \mathrm{SM}$ and continuous SM-treated flowers. However, the latter showed terminal diameter enlargement and mummification of the corolla.

The uptake of SM was determined by supplying radiolabelled SM. After $3 \mathrm{~h}$ of $25 \mathrm{mM} \mathrm{SM}$ treatment it accumulated in the corolla, ranging between 1 and $2 \mathrm{mM}$ in its proximal, medial or distal parts and after $24 \mathrm{~h}$ the estimated concentration was approximately $4 \mathrm{mM}$ in all three parts. Treatment with $50 \mathrm{mM}$ SM caused a higher uptake especially in the basal part and the rapid corolla decay (Supplementary information, Fig. S3).

\subsection{2- Cell parameters}

The most responsive flowers, i.e. those excised at stage 2-3, either treated or not treated with 25 $\mathrm{mM} \mathrm{SM}$ for $3 \mathrm{~h}$ were assayed for corolla fresh weight and anthocyanin, carotenoid, protein, and chlorophyll concentrations, as well as for the occurrence of DNA laddering as a criterion of dPCD occurrence (Figs. 6,7). Fresh weight did not change significantly as compared with controls up to $48 \mathrm{~h}$, but subsequently the weight of the SM-treated samples was $150 \%$ than the control (Fig. 6A). Protein levels were not significantly affected (Fig. 6B). Most of the SM-treated samples showed only a slight increase of pigment levels during the first $48 \mathrm{~h}$. Afterwards, SM delayed pigment decrease as for chlorophyll a and b and carotenoids, but SM also significantly enhanced the values as for anthocyanins (Fig. 6C, D, and E). SM treatment prevented the DNA laddering that occurs after $24 \mathrm{~h}$ in the corolla of untreated excised flowers and blocked its appearance even up to $96 \mathrm{~h}$ (Fig. 7).

\subsection{3- Distribution of TGase}

TGase was immuno-detected in petals of flowers excised at stage 2-3 and treated with $25 \mathrm{mM}$ SM for $3 \mathrm{~h}$ (Fig. 8A a, b). The signal accumulated along the outer border of the epidermal cells and to a lesser extent at the plasma membrane/cell wall interface of sub-epidermal cells. The internal parenchyma was characterized by large intercellular spaces among irregularly shaped cells with thin bended cell walls. TGase was found to accumulate as spots along the internal surface of cells (Fig. $8 \mathrm{~A} \mathrm{c}$, arrows). In untreated controls, TGase also accumulated along the outer border of the 
epidermal cells (Fig. 8B a, b), while in the inner parenchyma fluorescence was much less intense than in treated samples and cells were more regularly shaped (Fig. 8B c). In untreated controls, fluorescence intensity decreased dramatically, reaching almost zero value, from the epidermis towards the internal parenchyma, whereas it remained at $60 \%$ of the epidermal level in the more internal parenchyma cells of SM-treated samples (Fig. 8 C).

\section{4-DISCUSSION}

\section{1- Polyamines are involved in development and senescence of the $N$. tabacum flower corolla}

The development of the corolla, as shown by its increasing size and by the position and colour of its lobes, progresses from stages 1 to 5; thereafter, increasing rigidity signs the onset of senescence, as confirmed by present results on water transport.

The decrease in free PA concentrations from stage 2-3 up until stage 5 and onwards is in agreement with data reporting high free PA levels in dividing cells and lower ones in mature/senescing cells [23]. PA levels derive from the balance between biosynthesis, catabolism, and transport as well as conjugation $[8,38]$. PA content and biosynthesis were previously analyzed only at a very precocious stage in the whorls of developing tobacco flowers [39]. Present data show that TCA-soluble and insoluble bound PU and SD increased during corolla development and, in senescing petals, the high level of soluble PAs is in agreement with high level of TGase-conjugated glutamyl-PA previously detected in senescing $N$. tabacum petals [14], similarly to senescing chloroplasts of barley leaves [40]. The TCA-soluble PA peaks are concomitant with maximum opening of the corolla and the initiation of the AZ, that caused the block of water transport. The level of SM, the precursor (in the oxidative pathway) or product (in the biosynthetic pathway) of SD and PU [41], was always lower than that of the other two PAs, as in many other plant systems [16]. Despite its low levels, SM has important roles in plant development, including senescence and PCD [10,18]. In fact, a low, apparently negligible, concentration of a PA (like SM of the present paper) can mask its fine regulative role.

The subcellular localization of PAs and their binding to specific molecules i.e. cell wall components [42], are no doubt more indicative of their function. PAs interact with pectic substances and are responsible for the ordered packing of polygalacturonic chains $[43,44,45]$. PA oxidases are involved in lignification and in the cross-linking of extensin and polysaccharide-bound phenols $[38,46]$.

Moreover, hydroxycinnamoyl-PAs, the more relevant fraction among TCA-soluble PAs, are related to the cell walls organization [47,48], its extension [49] or rigidity [50]. The TCA-insoluble PAs deriving from free or TCA-soluble PAs bound to cell wall hemicelluloses and/or lignin [51] or to cell wall proteins via TGase [5] may form protein polymers or heteropolymers with polysaccharides. All these data underline the relevance of bound PAs in the cell walls. 


\section{2- TGase distribution in tegumental and parenchyma cells during corolla senescence}

During corolla development, TGase was immunolocalized almost exclusively in the epidermis, whereas during senescence it spread to the inner parenchyma. In both tissues, the enzyme was mainly localized in cell borders possibly in the cell walls. Similarly, in pollen tubes, the enzyme was present in the inner amorphous layer and in the outer fibrillar layer of the cell wall, mainly in the pollen tube growing region where it co-localizes with arabinogalactan proteins $[52,53]$.

The presence of TGase in the $N$. tabacum corolla epidermis can be related to the mechanical and protective role of this tissue and might also take part in morphological structural changes of the epidermal cell walls that take place during PCD [3]. The partial co-localization of TGase with cuticle suggests that TGase is involved in the process of waterproofing of the outer cell wall. When the TGase activity has been checked in the cell wall of $N$. tabacum L. corolla in the presence of ${ }^{14} \mathrm{C}$ SM the enzyme showed to be active [5]; the data reported in the present paper either with incubation of His6-Xpress GFP in tobacco epidermis and in onion transformation experiments, support the localization and the possible activity of TGase mainly at the cell border, indeed possibly in the cell wall. In the cell wall of growing pollen tubes, the His ${ }_{6}$-Xpress-GFP was substrate of pollen TGase; its presence stimulated tube length and germination [36]; moreover, TGase was released into growth medium catalyzing the cross-linking either of PAs and/or His 6 -Xpress-GFP to extracellular proteins, suggesting a possible role in cell adhesion [36,54]. The TGase action in the cell wall is supported by the observation that a $72 \mathrm{kDa}$ TGase is responsible for the assembly of glycoprotein in the wall of wall-regenerating cells in Chlamydomonas [55]. A similar structural role of TGase has been also proposed as defense mechanism during the progression of the hypersensitive reaction (HR) of resistant NN tobacco plants (N. tabacum L. cv. Samsun) to tobacco mosaic virus (TMV) [27].

During corolla senescence, the enzyme is located also in the inner parenchyma cells, whose walls become straight as well as auto-fluorescent, a clear sign of senescence modification due to lignification-suberification [14,19] process, in which phenolic compounds enrichment of the cell wall take place; a similar feature has been observed during anther dehiscence [20]. The corolla acquired a general rigidity, as confirmed by rheological studies showing a higher resistance to rupture and its tubular portion narrowed. The increasing presence of TGase in these parenchyma cells was consistent with the increase of TGase activity, measured by SM conjugation, in isolated cell wall fractions of senescing corolla; this increase was concomitant with the progression of corolla senescence until the last stage of dPCD [5]. Data from literature are consistent with a role of extracellular TGase as a modulator in the construction and stiffening of the cell wall $[36,55]$. The enzyme was also visible inside the corolla cells. Similarly, it was found in the cytoplasm of pollen, 
where it modified cytoskeleton proteins and was probably delivered via a membrane/cytoskeletonbased transport system and secreted in the cell wall [53].

The different localizations of TGase in N. tabacum are supported by data from the transformation experiments showing that TGase (AtPng1) was expressed in onion epidermal cells. The enzyme was present on the membranes of vesicles/organelles, on the plasmalemma and finally in cell wall where it likely accumulates. As suggested by the plasmolysis experiments, only AtPng1transformed onion cells at $\mathrm{pH} 7$ did not undergo plasmolysis, showing that the plasma membrane tied strongly to the cell wall where the enzyme is likely secreted and released in the cell wall of adjacent cells. In accordance, a positive correlation between resistance to hyper-osmotic stress and immediate rise of TGase activity was already observed in Dunaliella [56].

\section{3- The protective effect of spermine in the corolla depends on developmental stage and may be related to the TGase activity}

The developmental stage is of prime importance for the ability of plants to face adverse environmental conditions or initiate senescence [16,57]. Moreover, the developmental stage can influence the tolerance and /or the response of plants to abiotic stress like the salinity, since younger cells possess more potent ROS-scavenging mechanisms in comparison to their older counterparts [58]; developmental stage can affect also the response to biotic stressors, like in the case of tobacco leaves which were differentially susceptible to the metabolic products of Alternaria alternata [59]. In N. tabacum, the decay of excised flowers was regulated by SM either positively or negatively depending on the experimental conditions (concentration and duration of the treatment) and the developmental stage of the flower.

In fact, at very early stages, SM supply delayed or blocked the corolla development, while it accelerated senescence in later stages. Only flowers whose developmental program was already determined, namely at stages 2-4, maintained good conditions after excision; in these flowers, SM caused a further expansion of the corolla lobes and delayed the first signs of senescence. Prevention of the AZ formation allowed the maintenance of the water supply and prevented wilting of the corolla.

SM can have been metabolized to several compounds including shorter PAs [12,60] thereby leading to the high levels of PU and SD characteristic of the growing corolla. The endogenous concentration of SM or its derivatives after $3 \mathrm{~h}$ of treatment was 1-2 $\mathrm{mM}$, a value that seemed to be high, but which favoured the delay of senescence; however, this value is not so far from the physiological one, being SM present at millimolar concentrations in the nucleus [15]. By contrast, the values reached after the $24 \mathrm{~h}$ treatment ( $4 \mathrm{mM}$ or more) caused a rapid damage and death of the corolla. These concentrations are probably overestimated as most of the SM solution taken up likely 
remains inside the large vessels to be transported to different target tissues; i.e. it is known that PAs are translocated by vessels to guard cells where PAs reduces transpiration by inhibiting stomata opening [61]. In the present paper, after the optimal SM treatment, DNA-laddering was delayed even up to $96 \mathrm{~h}$, i.e. a much longer period than that ( 24 - $48 \mathrm{~h}$ ) observed in flowers at stage 5 treated continuously with $5 \mathrm{mM} \mathrm{SM} \mathrm{[14],} \mathrm{confirming} \mathrm{its} \mathrm{protective} \mathrm{role} \mathrm{in} \mathrm{the} \mathrm{excised} \mathrm{flowers.} \mathrm{SM} \mathrm{is} \mathrm{also}$ known to bind to nucleic acids and to stabilize them [62,63]; in addition, histones and SM are both TGase substrates [64,65] and this could explain the stabilizing role of TGase against DNAladdering. In N. tabacum, as a results of TGase catalysis, bis-( $\gamma$-glutamyl)-PA formation, indicative of linkages among proteins and thus of their stabilization, decreased after DNA-laddering whereas that of mono-( $\gamma$-glutamyl)-PAs increased, suggesting that some inter- or intra-molecular bridges were broken [14]. Other parameters, namely chlorophylls, carotenoids, and anthocyanins were affected by SM supply. Their contents were lower than in controls during the first $48 \mathrm{~h}$, but afterwards became much higher. Whereas the plastidial pigments decreased after $72 \mathrm{~h}$, the vacuolar ones remained at a high level. These data are in agreement with those on Lactuca, where SM sprayed on leaves was shown to delay the decay of chloroplast photosystems and to cause an increase of TGase activity conjugating SM to chloroplast proteins, mainly PSII and PSI [13]. Similarly, the high concentrations of chlorophylls and carotenoids in the N. tabacum corolla may be due to the stabilization of photosystems by SM, as observed in N. tabacum leaf discs [66], being photosystems the preferential substrates of chloroplast TGase [33,67]. This could lead to increased energy supply to the corolla for longer periods.

Anthocyanins were maintained at very high concentrations, at least until $96 \mathrm{~h}$, indicating that the vacuoles had not been dismantled [14]. Although tonoplast rupture cannot be considered the last committed step leading to PCD, it is a sign of cell decay [68]. Present data, concerning the effect on flower pigments in vacuoles and chloroplasts after SM-treatment, are in agreement with the protective role exerted by PAs on cell membranes [69]. Moreover, the parenchyma cells in the corollas of SM-treated flowers were very different in morphology from those of in in planta senescing corollas, because only the former underwent cell expansion, possibly as a consequence of a modified hormonal balance [6,7]. As an example, production or activity of ethylene, which regulates flower senescence [70,71], was inhibited and senescence was delayed in $N$. tabacum flowers treated with PAs [14].

According to [72] the supply of SM to N. tabacum corolla, caused a higher and precocious accumulation of TGase in the cell wall of the parenchyma cells; TGase apparently does not act as a strengthening/stiffening factor (as in senescent cells), but it is probably involved in stimulating cell expansion. In these cells, the mechanism of SM action can be likely direct: being SM a TGase substrate, when supplied at high concentrations it might compete for the glutamyl substrate, 
favouring the formation of mono-PA-glutamyl derivatives rather than bis-PAs or glutamyl-lysine cross linkages, previously detected in the corolla [14]. These data could support the hypothesis that the formation of fewer cross-linkages among proteins might possibly reduce the strength of the protein net, allowing cell walls to expand. In accordance, the corolla tubular portion did not close at all under continuous supply of SM. Cell wall modification by TGase was observed to be modulated by PAs in the alga Chlamydomonas, where the addition of PAs at high concentrations disrupts the normal wall assembly [55]. This proposed mechanism does not exclude that SM or its derivatives could also interact with other cell wall components, or affect the expression of other enzymes involved in cell wall modification [7].

In conclusion, the positive effects of optimal concentrations of SM in delaying senescence of excised tobacco flowers is suggested by several evidences, such as the prolonged corolla expansion and pigmentation, the delayed closure of the tubular portion, and the absence of DNA-laddering as well as of the AZ. These findings are indicative of the action of PAs as growth factors. Not only was the progression of senescence slowed down, but PAs also induced a change in the developmental program leading to $\mathrm{APCD}$, a relevant aspect also for applicative purposes, i.e. in agriculture. The corolla was, however, capable of a positive response to SM only in a narrow developmental/hormonal window; this might explain why PAs have been reported to exert contradictory effects on PCD.

Takahashi and Kakehi [15] concluded their review on the double-edged role of SM acting both as radical scavenger and as source of free radicals in the apoplast by stating "the possibility cannot be ruled out that the interaction of spermine with other molecules is involved in cell death". The presence and induction of TGase in the corolla cell wall, as regulated by the SM supply, is in agreement with the possibility of a SM/TGase interaction, suggesting TGase as an important factor in petal morphogenesis and dPCD.

\section{5- SUPPLEMENTARY INFORMATION}

To characterize the changes occurring along the corolla of flowers at different stages, the fresh and dry weights were measured in the entire corolla in each of the stages and in three sections of the corolla - proximal (P), median (M) and distal (D) - obtained by cutting it transversely (Fig. S1). The fresh weight increase of the corolla clearly reflected visible growth and development, its decrease senescence and death, and was therefore considered a useful tool to unequivocally identify the stages.

Supplementary material related to this article found, in the online version, at doi:10.1016/j.plantsci.2015.09.023. 
mmc1

Distribution of TGase in parenchyma cells by immunolocalization with an anti- TGase antibody (Fig. S2). A and B. Labelling with anti-TGase antibody of SM-treated flower showing fluorescent signals at cell borders (plasmatic membrane/ cell wall, arrowhead) and inside parenchyma cells (cytosol/organelles, arrows). C. Negative control performed without the primary anti-TGase antibody. Bars: $20 \mu \mathrm{m}$

Supplementary material related to this article found, in the online version, at doi:10.1016/j.plantsci.2015.09.023.

mmc2

To evaluate the content of SM or its derivatives in three sections of $N$. tabacum corolla of flowers excised at stage 2-3 treated with SM, the pedicels of flowers were immersed in a solution containing 25 or $50 \mathrm{mM} \mathrm{SM}$ in the presence of $\left.0.2 \mathrm{mM} \mathrm{[}{ }^{14} \mathrm{C}\right] \mathrm{SM}$ for $1,3 \mathrm{~h}$ and then left in water for $24 \mathrm{~h}$, or left continuously in SM for $24 \mathrm{~h}$ (Fig. S3). The corolla was sectioned in: proximal (P), median (M) and distal (D) parts. The differences between the correspondent parts (P/P, M/M) of flowers treated with $25 \mathrm{mM}$ or $50 \mathrm{mM}$ for $1,3,24 \mathrm{~h}$ were significant at at 0.01 . Standard deviation $<10 \%$.

Supplementary material related to this article found, in the online version, at doi:10.1016/j.plantsci.2015.09.023.

mmc3 


\section{6- ACKNOWLEDGEMENTS}

This work was supported by funds from the University of Bologna [Ricerca Fondamentale Orientata 11deldu] to SDD. We thank PhD V. Genovesi (formerly Dip. Biologia Evoluzionistica Sperimentale, Università di Bologna), Dr. C. Del Casino (Dip. Scienze della Vita, Università di Siena) for their contribution in planning the biolistic experiment. Mr. N. Mele (Dip. Scienze Biologiche, Geologiche e Ambientali, Università di Bologna) is acknowledged for photographic and image assistance. 


\section{LITERATURE}

1. Tabor CW, Tabor H (1984) Polyamines. Annu Rev Biochem 53: 749-790.

2. Kusano T, Berberich T, Tateda C, Takahashi Y (2008) Polyamines: essential factors for growth and survival. Planta 228: 367-381.

3. Van Hautegem T, Waters AJ, Goodrich J, Nowack MK (2015) Only in dying, life: programmed cell death during plant development. Trends Plant Sci 20: 102-113.

4. Della Mea M, Serafini-Fracassini D, Del Duca S (2007) Programmed cell death: similarities and differences in animals and plants. A flower paradigm. Amino Acids 33: 395-404.

5. Della Mea M, De Filippis F, Genovesi V, Serafini Fracassini D, Del Duca S(2007) The acropetal wave of developmental cell death of tobacco corolla is preceded by activation of transglutaminase in different cell compartments. Plant Physiol 144: 1211-1222.

6. Amasino RM, Michaels SD (2010) The timing of flowering. Plant Physiol 154: 516-520.

7. Rogers HJ (2013) From models to ornamentals: how is flower senescence regulated? Plant Mol Biol 82: 563-574.

8. Bachrach U, authors v (2010) Special issue on Polyamines. Plant Physiology and Biochemistry 48: 487-634.

9. Seiler N, Raul F (2005) Polyamines and apoptosis. J Cell Mol Med 9: 623-642.

10. Del Duca S, Serafini-Fracassini D, Cai G (2014) Senescence and programmed cell death in plants: polyamine action mediated by transglutaminase. Front Plant Sci 5: 120.

11. Evans P, Malmberg R (1989) Do polyamines have roles in plant development? Annu Rev Plant Physiol Plant Mol Bio 40: 235-269

12. Moschou PN, Roubelakis-Angelakis KA (2014) Polyamines and programmed cell death.J Exp Bot 65: 1285-1296.

13. Serafini-Fracassini D, Di Sandro A, Del Duca S (2010) Spermine delays leaf senescence in Lactuca sativa and prevents the decay of chloroplast photosystems. Plant Physiol Biochem 48: 602-611.

14. Serafini-Fracassini D, Del Duca S, Monti F, Poli F, Sacchetti G, et al. (2002)

Transglutaminase activity during senescence and programmed cell death in the corolla of tobacco (Nicotiana tabacum) flowers. Cell Death Differ 9: 309-321.

15. Takahashi T, Kakehi J (2010) Polyamines: ubiquitous polycations with unique roles in growth and stress responses. Ann Bot 105: 1-6.

16. Bagni N, Tassoni A (2006) The role of polyamines in relation to flower senescence. Teixeira da Silva JA Floriculture, ornamental and plant biotechnology: 88-95.

17. Ebrahimzadeh A, Jiménez-Becker S, Chaparro-Torres LA, Fernandez-Trujillo JP, SerranoMula M, et al. (2013) Postharvest petal senescence of two cultivars of carnation flowers with different vase lives. AJCS 12: 1829-1835.

18. Mehta RA, Cassol T, Li N, Ali N, Handa AK, et al. (2002) Engineered polyamine accumulation in tomato enhances phytonutrient content, juice quality, and vine life. Nature Biotechnology 20: 613-618.

19. Heath MC (1984) Relationship between heat-induced fungal death and plant necrosis in compatible and incompatible interactions involving the bean and cowpea rust fungi. Phytopatology 61: 383- 388.

20. Wilson ZA, Song J, Taylor B, Yang C (2011) The final split: the regulation of anther dehiscence. J Exp Bot 62: 1633-1649.

21. Griffin M, Casadio R, Bergamini CM (2002) Transglutaminases: nature's biological glues. Biochem J 368: 377-396.

22. Beninati S, Bergamini CM, Piacentini M (2009) An overview of the first 50 years of transglutaminase research. Amino Acids 36: 591-598. 
23. Cai G, Sobieszczuk-Nowicka E, Aloisi I, Fattorini L, Serafini-Fracassini D, et al. (2015) Polyamines are common players in different facets of plant programmed cell death. Amino Acids 47: 27-44.

24. Beninati S, Iorio RA, Tasco G, Serafini-Fracassini D, Casadio R, et al. (2013) Expression of different forms of transglutaminases by immature cells of Helianthus tuberosus sprout apices. Amino Acids 44: 271-283.

25. Fesus L, Szondy Z(2005) Transglutaminase 2 in the balance of cell death and survival. FEBS Lett 579: 3297-3302.

26. Del Duca S, Cai G, Di Sandro A, Serafini-Fracassini D (2010) Compatible and selfincompatible pollination in Pyrus communis displays different polyamine levels and transglutaminase activity. Amino Acids 38: 659-667.

27. Del Duca S, Betti L, Trebbi G, Serafini-Fracassini D, Torrigiani P (2007) Transglutaminase activity changes during the hypersensitive reaction, a typical defense response of tobacco NN plants to TMV. Physiol Plant 131: 241-250.

28. Sobieszczuk-Nowicka E, Zmienko A, Samelak-Czajka A, Luczak M, Pietrowska-Borek M, et al. (2015) Dark-induced senescence of barley leaves involves activation of plastid transglutaminases. Amino Acids 47: 825-838.

29. Del Duca S, Verderio E, Serafini-Fracassini D, Iorio R, Cai G (2014) The plant extracellular transglutaminase: what mammal analogues tell. Amino Acids 46: 777-792.

30. Lowry OH, Rosebrough NJ, Farr AL, Randall RJ (1951) Protein measurement with the Folin phenol reagent. Journal of Biological Chemistry 193 265-275.

31. Torrigiani P, Rabiti AL, Betti L, Marani F, Brizzi M, et al. (1995) Improved method for polyamine determination in TMV, a rod-shaped virus. J Virol Methods 53: 157-163.

32. Cai G, Faleri C, Del Casino C, Hueros G, Thompson RD, et al. (2002) Subcellular localisation of BETL-1, -2 and -4 in Zea mays L. endosperm. Sexual Plant Reproduction 15: 85-98.

33. Della Mea M, Caparros-Ruiz D, Claparols I, Serafini-Fracassini D, Rigau J (2004) AtPng1p. The first plant transglutaminase. Plant Physiol 135: 2046-2054.

34. Furutani Y, Kato A, Notoya M, Ghoneim MA, Hirose S (2001) A simple assay and histochemical localization of transglutaminase activity using a derivative of green fluorescent protein as substrate.J Histochem Cytochem 49: 247-258.

35. Genovesi V, Fornalé S, Fry SC, Ruel K, Ferrer P, et al. (2008) ZmXTH1, a new xyloglucan endotransglucosylase/ hydrolase in maize, affects cell wall structure and composition in Arabidopsis thaliana. Journal of Experimental Botany 59: 875-889.

36. Di Sandro A, Del Duca S, Verderio E, Hargreaves AJ, Scarpellini A, et al. (2010) An extracellular transglutaminase is required for apple pollen tube growth. Biochem J 429: 261-271.

37. Chen AP, Zhong NQ, Qu ZL, Wang F, Liu N, et al. (2007) Root and vascular tissue-specific expression of glycine-rich protein AtGRP9 and its interaction with AtCAD5, a cinnamyl alcohol dehydrogenase, in Arabidopsis thaliana. J Plant Res 120: 337-343.

38. Angelini R, Cona A, Federico R, Fincato P, Tavladoraki P, et al. (2010) Plant amine oxidases "on the move": an update. Plant Physiol Biochem 48: 560-564.

39. Scaramagli S, Franceschetti M, Michael AJ, Torrigiani P, Bagni N (1999) Polyamines and flowering: Spermidine biosynthesis in the different whorls of developing flowers of Nicotiana tabacum L. . Plant Biosystem 133 229-237.

40. Sobieszczuk-Nowicka E, Wieczorek P, Legocka J (2009) Kinetin affects the level of chloroplast polyamines and transglutaminase activity during senescence of barley leaves. Acta Biochim Pol 56: 255-259.

41. Smith TA (1985 ) Polyamines. Annual Review of Plant Physiology 36:: 117-143.

42. Biasi R, Falasca G, Speranza A, De Stradis A, Scoccianti V, et al. (2001) Biochemical and ultrastructural features related to male sterility in the dioecious species Actinidia deliciosa. Plant Physiol Biochem 39: 395-406. 
43. Berta G, Altamura MM, Fusconi A, Cerruti F, Capitani F, et al. (1997) The plant cell wall is altered by inhibition of polyamine biosynthesis. New Phytologist 137: 569-577.

44. D'Orazi D, Bagni N (1987) In vitro interactions between polyamines and pectic substances. Biochemical and Biophysical Research Communications 148 1259-1263.

45. Lenucci M, Piro G, Miller JG, Dalessandro G, Fry SC (2005) Do polyamines contribute to plant cell wall assembly by forming amide bonds with pectins? Phytochemistry 66: 2581-2594.

46. Yoda H, Hiroi Y, Sano H (2006) Polyamine oxidase is one of the key elements for oxidative burst to induce programmed cell death in tobacco cultured cells. Plant Physiol 142: 193-206.

47. Grienenberger E, Besseau S, Geoffroy P, Debayle D, Heintz D, et al. (2009) A BAHD acyltransferase is expressed in the tapetum of Arabidopsis anthers and is involved in the synthesis of hydroxycinnamoyl spermidines. Plant J 58: 246-259.

48. Tuyet Lam TB, Iiyama K, Stone BA (1992) Cinnamic acid bridges between cell wall polymers in wheat and phalaris internodes. Phytochemistry 31: 1179-1183.

49. Iiyama K, Lam T, Stone BA (1994) Covalent Cross-Links in the Cell Wall. Plant Physiol 104: 315-320.

50. Bassard JE, Ullmann P, Bernier F, Werck-Reichhart D (2010) Phenolamides: bridging polyamines to the phenolic metabolism. Phytochemistry 71: 1808-1824.

51. Antognoni F, Bagni N (2008) Bis(guanylhydrazones) negatively affect in vitro germination of kiwifruit pollen and alter the endogenous polyamine pool. Plant Biol (Stuttg) 10: 334-341.

52. Del Duca S, Serafini-Fracassini D, Cai G (2013) An unconventional road for the secretion of transglutaminase in pollen tubes? Plant Signal Behav 8: e24446.

53. Del Duca S, Faleri C, Iorio RA, Cresti M, Serafini-Fracassini D, et al. (2013) Distribution of transglutaminase in pear pollen tubes in relation to cytoskeleton and membrane dynamics. Plant Physiol 161: 1706-1721.

54. Iorio RA, Di Sandro A, Paris R, Pagliarani G, Tartarini S, et al. (2012) Simulated environmental criticalities affect transglutaminase of Malus and Corylus pollens having different allergenic potential. Amino Acids 42: 1007-1024.

55. Waffenschmidt S, Kusch T, Woessner JP (1999) A transglutaminase immunologically related to tissue transglutaminase catalyzes cross-linking of cell wall proteins in Chlamydomonas reinhardtii. Plant Physiol 121: 1003-1015.

56. Dondini L, Bonazzi S, Del Duca S, Bregoli AM, Serafini-Fracassini D (2001) Acclimation of chloroplast transglutaminase to high NaClconcentration in a polyamine-deficient variant strain of Dunaliella salina and in its wild type. . Journal of Plant Physiology 158: 185-197.

57. Petrov V, Hille J, Mueller-Roeber B, Gechev TS (2015) ROS-mediated abiotic stress-induced programmed cell death in plants. Front Plant Sci 6: 69.

58. Kravchik M, Bernstein N (2013) Effects of salinity on the transcriptome of growing maize leaf cells point at cell-age specificity in the involvement of the antioxidative response in cell growth restriction. BMC Genomics 14: 24 .

59. Jia C, Zhang L, Liu L, Wang J, Li C, et al. (2012) Multiple phytohormone signalling pathways modulate susceptibility of tomato plants to Alternaria alternata f. sp. lycopersici. J Exp Bot.

60. Del Duca S, Beninati S, Serafini-Fracassini D (1995) Polyamines in chloroplasts: identification of their glutamyl and acetyl derivatives. . Biochemical Journal 305: 233237.

61. Shu S, Guo SR, Yuan LY (2012) A review: polyamines and photosynthesis. Advances in photosynthesis-fundamental aspectsInTech, Rijeka 439-464. 
62. D'Agostino L, di Pietro M, Di Luccia A (2005) Nuclear aggregates of polyamines are supramolecular structures that play a crucial role in genomic DNA protection and conformation. FEBSJ 272: 3777-3787.

63. D'Orazi D, Fracassini DS, Bagni N (1979) Polyamine effects on the stability of DNAactinomycin D complex. Biochem Biophys Res Commun 90:362-367.

64. Ballestar E, Franco L (1997) Use of the transglutaminase reaction to study the dissociation of histone N-terminal tails from DNA in nucleosome core particles. Biochemistry 36 : 5963-5969.

65. Sato N, Ohtake Y, Kato H, Abe S, Kohno H, et al. (2003) Effects of polyamines on histone polymerization. Journal of Protein Chemistry 22 303-307.

66. Ioannidis NE, Kotzabasis K (2007) Effects of polyamines on the functionality of photosynthetic membrane in vivo and in vitro. Biochim Biophys Acta 1767: 13721382.

67. Sobieszczuk-Nowicka E, Di Sandro A, Del Duca S, Serafini-Fracassini D, Legocka J (2007) Plastid-membrane-associated polyamines and thylakoid transglutaminases during etioplast-to-chloroplast transformation stimulated by kinetin Physiologia Plantarum 130: 590-600.

68. van Doorn WG, Woltering EJ (2010) What about the role of autophagy in PCD? . Trends in Plant Science 15: 361-362.

69. Tassoni A, Antognoni F, Bagni N (1996) Polyamine binding to plasma membrane vesicles isolated from zucchini hypocotyls. Plant Physiology 110: 817-824.

70. Martin-Tanguy J (1996) Flowering, polyamines, inhibitors of polyamine and ethylene biosynthesis. Flower Newsletters 21: 10-20.

71. Woltering EJ, van Doorn WG (1988) Role of ethylene in senescence of petals morphological and taxonomical relationships. Journal of Experimental Botany 39: 1605-1616.

72. Chen JS, Mehta K (1999) Tissue transglutaminase: an enzyme with a split personality. Int J Biochem Cell Biol 31: 817-836.

\section{FIGURE LEGENDS}

Figure 1. Transport efficiency of the corolla of $N$. tabacum flower at different developmental stages. Uptake by proximal part and transport to distal corolla part of methyl green dye as evaluated by immersing the flower pedicel in the dye solution.

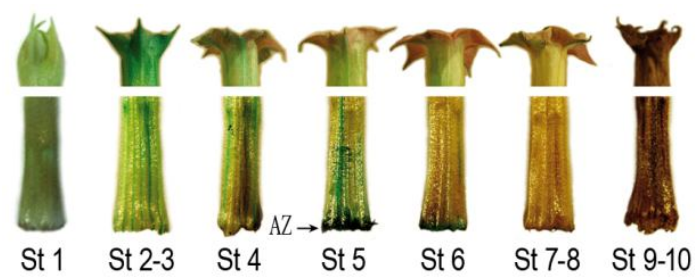

Figure 2. Polyamine content in the corolla of $N$. tabacum flower at different developmental stages. A. Free polyamines. B. TCA-soluble polyamines. C. TCA-insoluble polyamines. Putrescine 
(PU); spermidine (SD); spermine (SM). Symbols labeled by the same letter are not significantly different. The free PA content decreased significantly from the stage 2-3 until stage 4-5 (A). The SD content was significantly greater than PU only in the insoluble fraction (C); the insoluble SD content tended to significantly decrease between stage 2-3 and 6 .

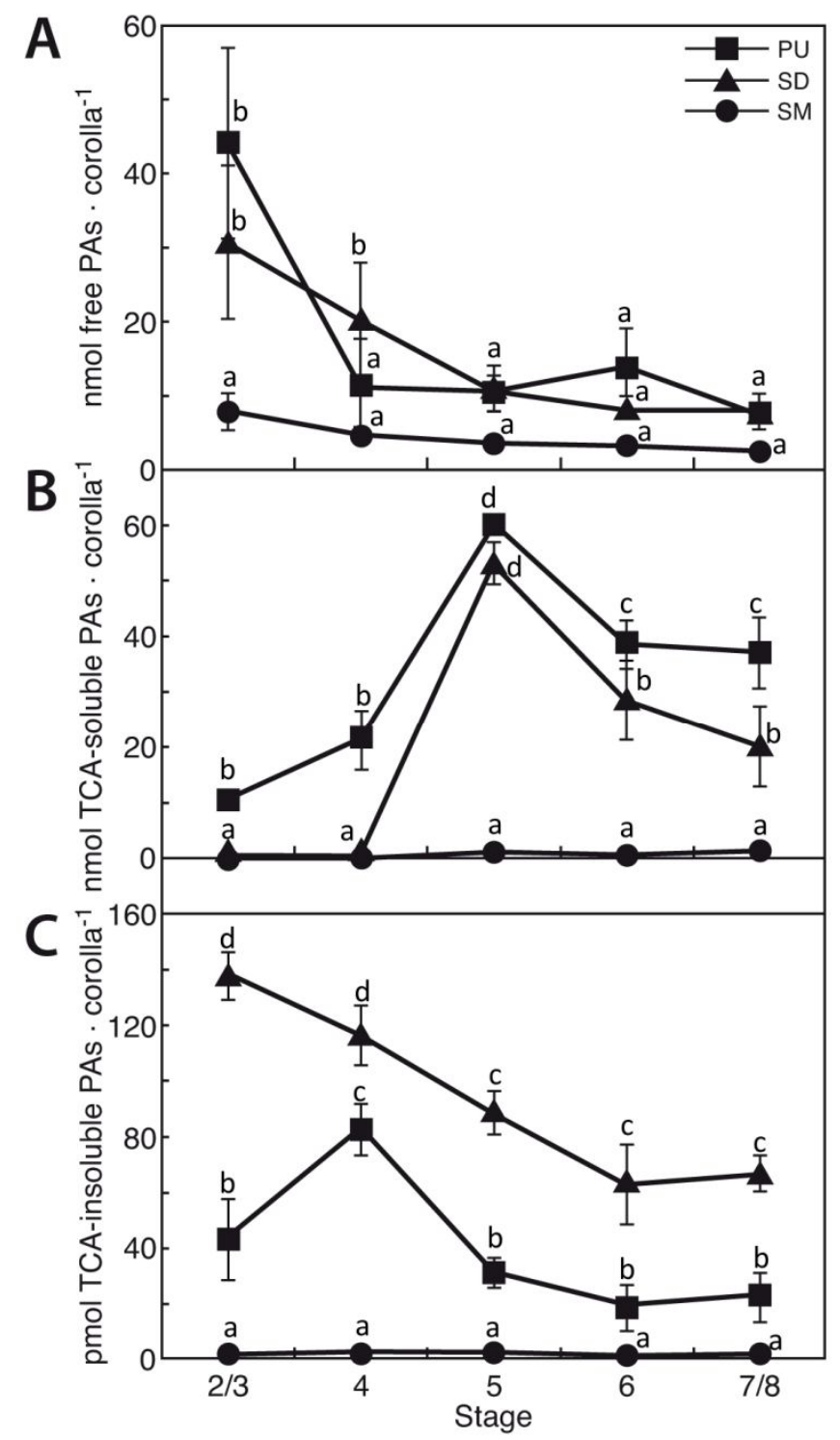

Figure 3. Distribution of TGase in the corolla of $\boldsymbol{N}$. tabacum flowers at stage 4 and 6. A. Stage 4 of the lifespan. The top left cartoon indicates the areas of the flower petal labelled by anti-TGase antibody. $\left(a_{1}\right)$ Labelling on the external (abaxial) side of tobacco petal. $\left(a_{2}\right)$ Same area stained for cuticle. (b) Labelling on the internal (adaxial) side. (c) Abaxial side. (d) Entire section of petal from abaxial (external, ext) to adaxial (internal, int) side. (e) Detail of inner parenchyma cells. Bars $=a_{1}-a_{2}$ : $20 \mu \mathrm{m}$; b-c-d: $50 \mu \mathrm{m}$; e: $20 \mu \mathrm{m}$. B. Stage 6 of the lifespan. $\left(a_{1}\right)$ Abaxial side. $\left(a_{2}\right)$ Staining for cuticle. (b) Adaxial side. (c) Abaxial side. (d) Entire section of petal from abaxial (ext) to adaxial (int) side. 
(e) Detail of inner parenchyma cells showing labelling in the cell wall. Bars: $50 \mu \mathrm{m}$.

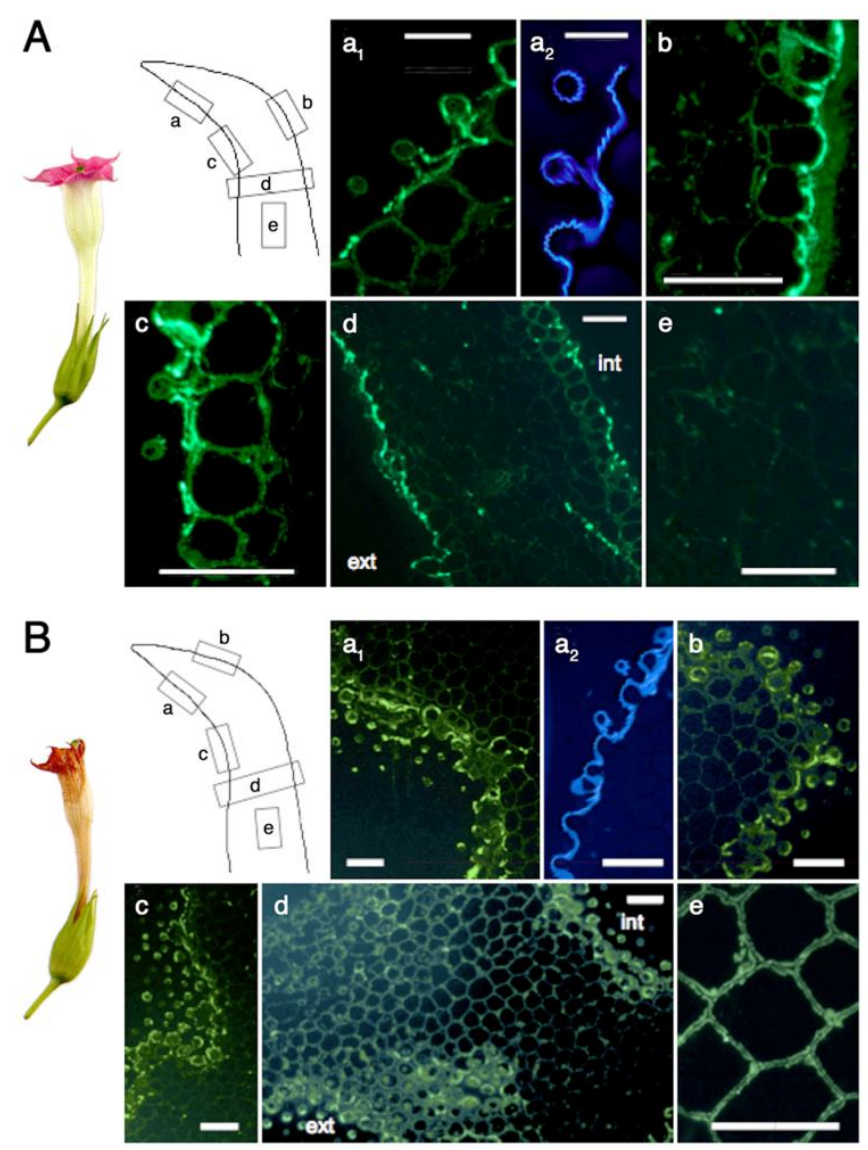

Figure 4. Epidermal cells labelled by the recombinant fluorescent substrate of the mammalian TGase (histidine-tagged green fluorescent protein: His $_{6}$-Xpress-GFP) (A) or transformed with a construct encoding GFP-TGase fusion protein (GFP+AtPng1) (B-D). A. Epidermal cells of $N$. tabacum corolla at stage 6: autofluorescence of control untreated cells (a) and after incubation in situ with modified GFP (His ${ }_{6}$ Xpress-GFP) for $30 \mathrm{~min}$ (b). Bars: $50 \mu \mathrm{m}$. B, C, D. Epidermal cells of onion cataphylls transformed with a construct encoding GFP (GFP, control) or GFP-TGase fusion protein $(G F P+A t P n g l)$ at two different $\mathrm{pH}$ (5.8 and 7.0) for $24 \mathrm{~h}$. B (a, b, c, d). Representative samples of the four experiments (GFP or GFP+AtPngl at the two pH values). Bars: $100 \mu \mathrm{m}$; the detail in the inset of figure $\mathbf{B}$ (d) shows fluorescent cytoplasmic organelles/vesicles. Bars: $10 \mu \mathrm{m}$. $\mathbf{C}$. Cell transformed with GFP+AtPngl at pH 5.8 (a) or pH 7 (c) or with GFP alone at pH 7 (b); Bars: 50 $\mu \mathrm{m}$; details of cell wall ( $\mathrm{c}_{1}$, Bar $\left.10 \mu \mathrm{m}\right)$; samples in a, b, c were subjected to plasmolysis; cells which 
were effectively plasmolyzed are indicated by $(p)$, those not plasmolyzed with $(n p)$. D. (a) detail of the cytoplasmic membranes, (b) cell walls, (c) border between $n p$ and $p$ cells after labelling with GFP+AtPngl at pH 7. (b) Detail of the cell walls of C (c); (c) detail of the border between $n p$ and $p$ cells of C (c). Bars: $5 \mu \mathrm{m}$ in D (a), $70 \mu \mathrm{m}$ in D (b), $50 \mu \mathrm{m}$ in D (c). 


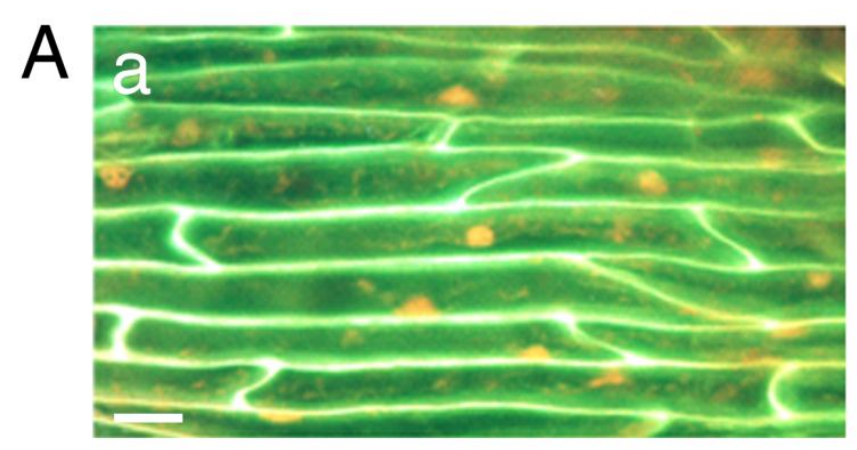

Autofluorescence

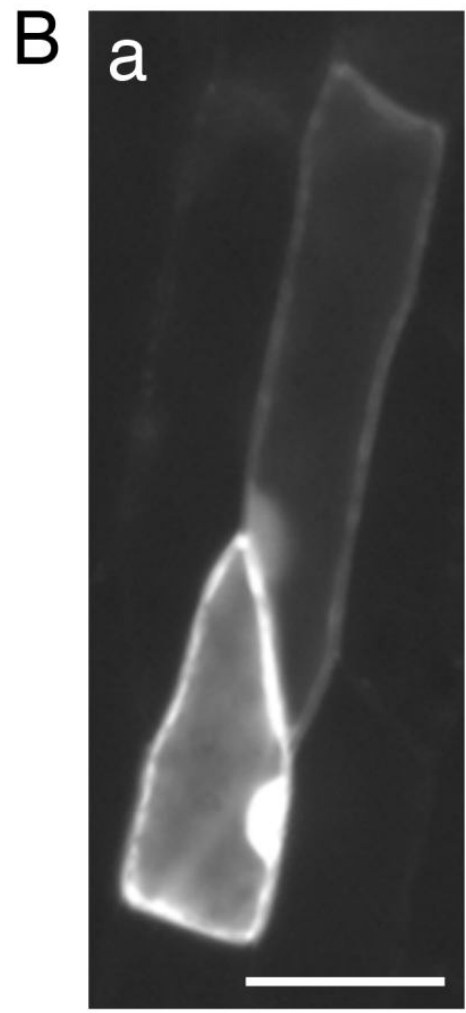

GFP pH 5.8

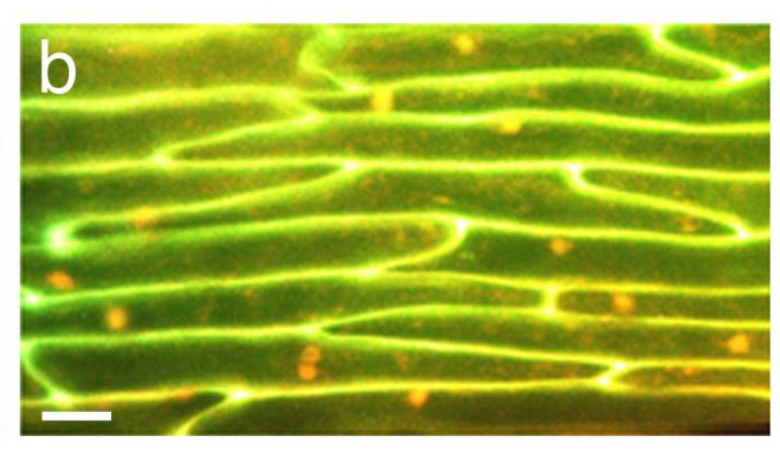

$\mathrm{His}_{6}-$ Xpress-GFP

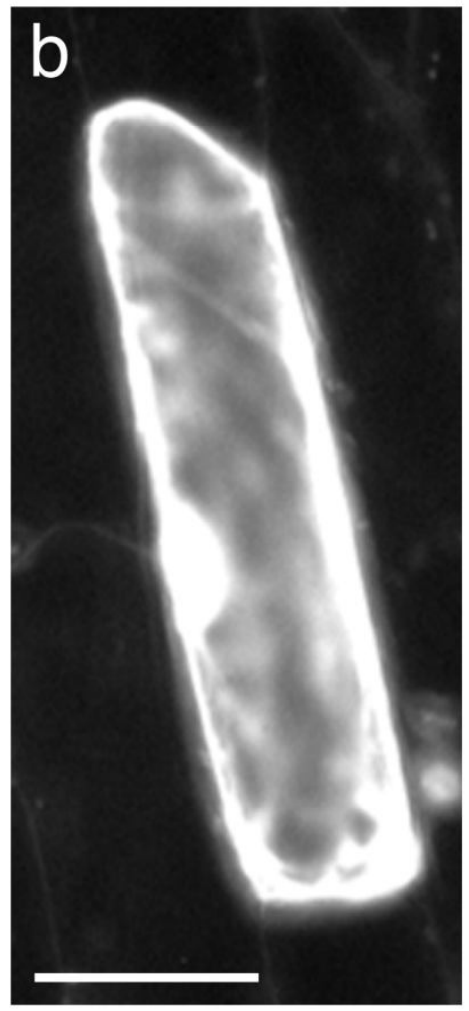

GFP + AtPng1

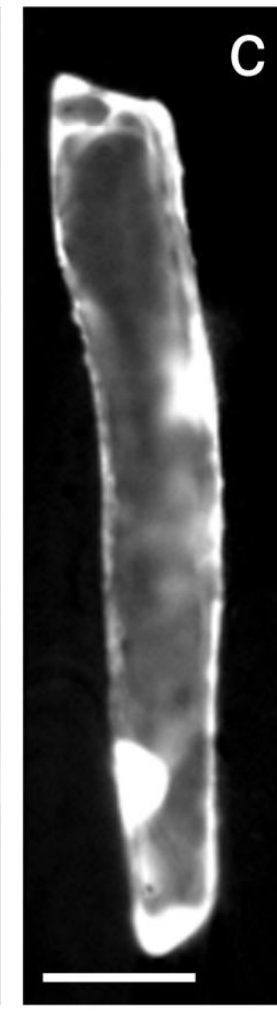

GFP $\mathrm{pH} 7.0$

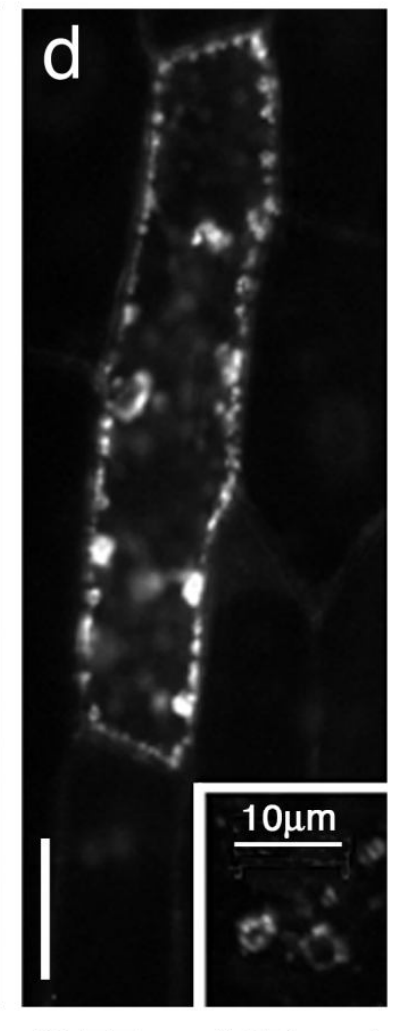

GFP + AtPng1

C
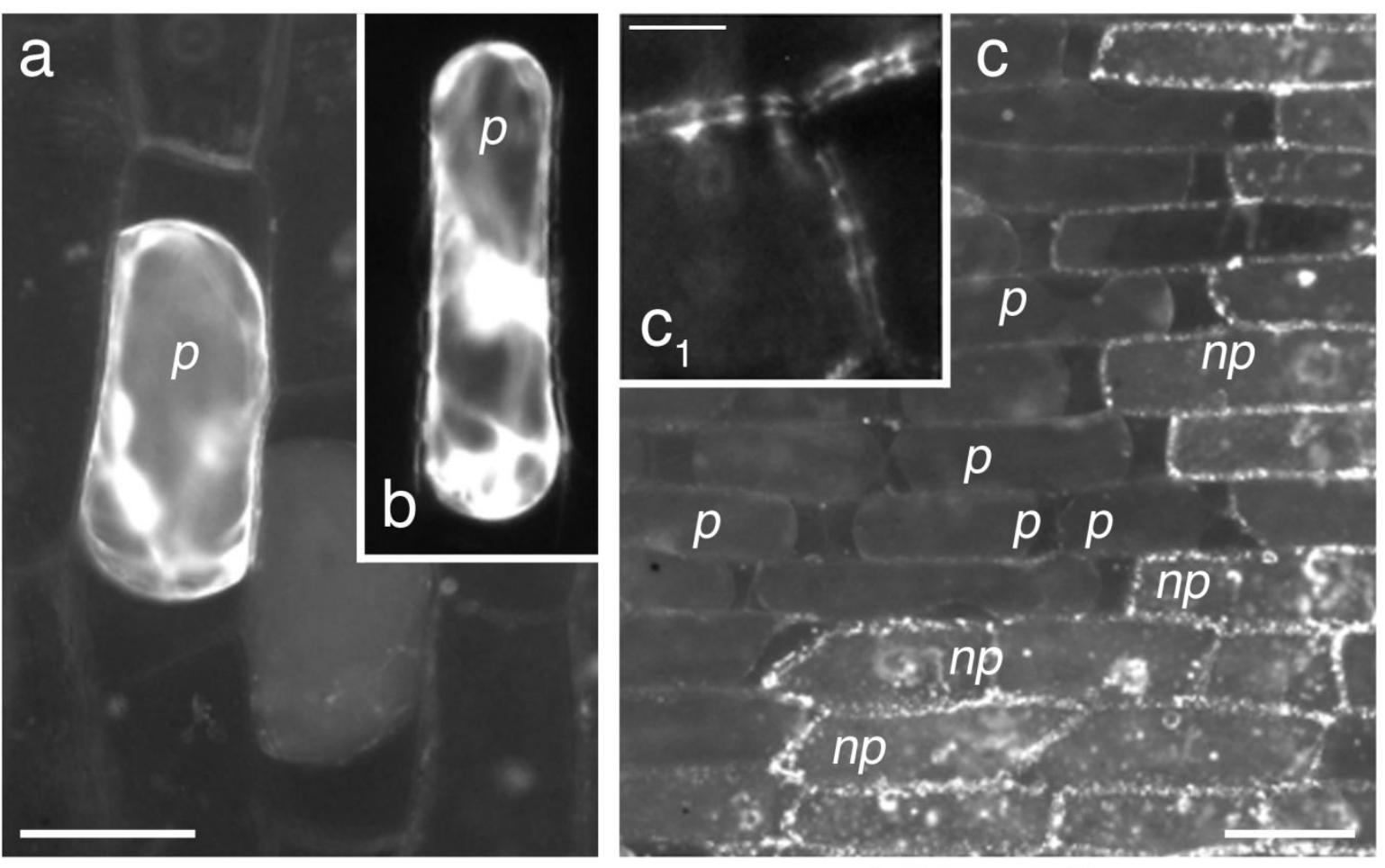

$p$ $p p$

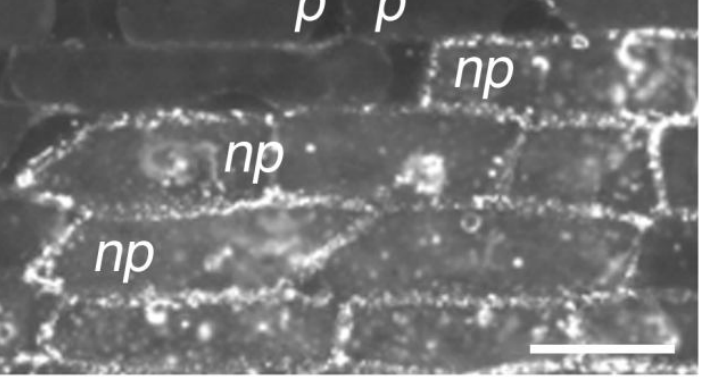


Figure 5. The effect of $25 \mathrm{mM}$ SM on the corolla of $N$. tabacum flowers excised at different stages. A. Pedicels of flowers were immersed in the SM solution for $3 \mathrm{~h}$ and then transferred in water until the $96^{\text {th }} \mathrm{h}$, or left in water for $96 \mathrm{~h}$ as control. Some experiments were terminated as indicated (i.e. 48 and $72 \mathrm{~h}$ ), when no further changes or death of flowers occurred. B. The distal part of the corolla (stage 2-3) at the $96^{\text {th }} \mathrm{h}$. Pedicels of flowers excised at stage 2-3 were immersed in the SM solution for 1 or $3 \mathrm{~h}$ and then transferred in water, or left in continuous; the control was left in water throughout the experiment. C. The diameters of the cylindrical part of the tubular corolla of not excised flowers (in planta) or excised at stage 2-3, were measured up to $120 \mathrm{~h}$. The differences at 120 $\mathrm{h}$ between water-treated and "in planta" are significantly different from treated in continuous with SM (SM cont) or for $3 h$. $* *=p \leq 0.01$. The yellow labelled $\mathbf{b}$ and $\mathbf{c}$ indicate distal and tubular part of the flower corolla. 


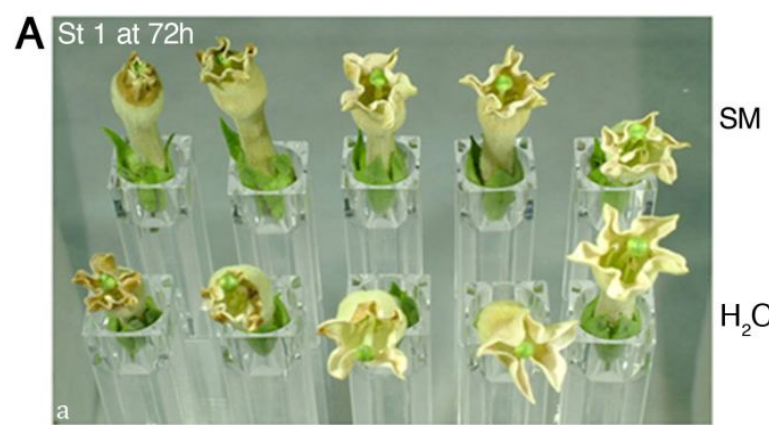

B
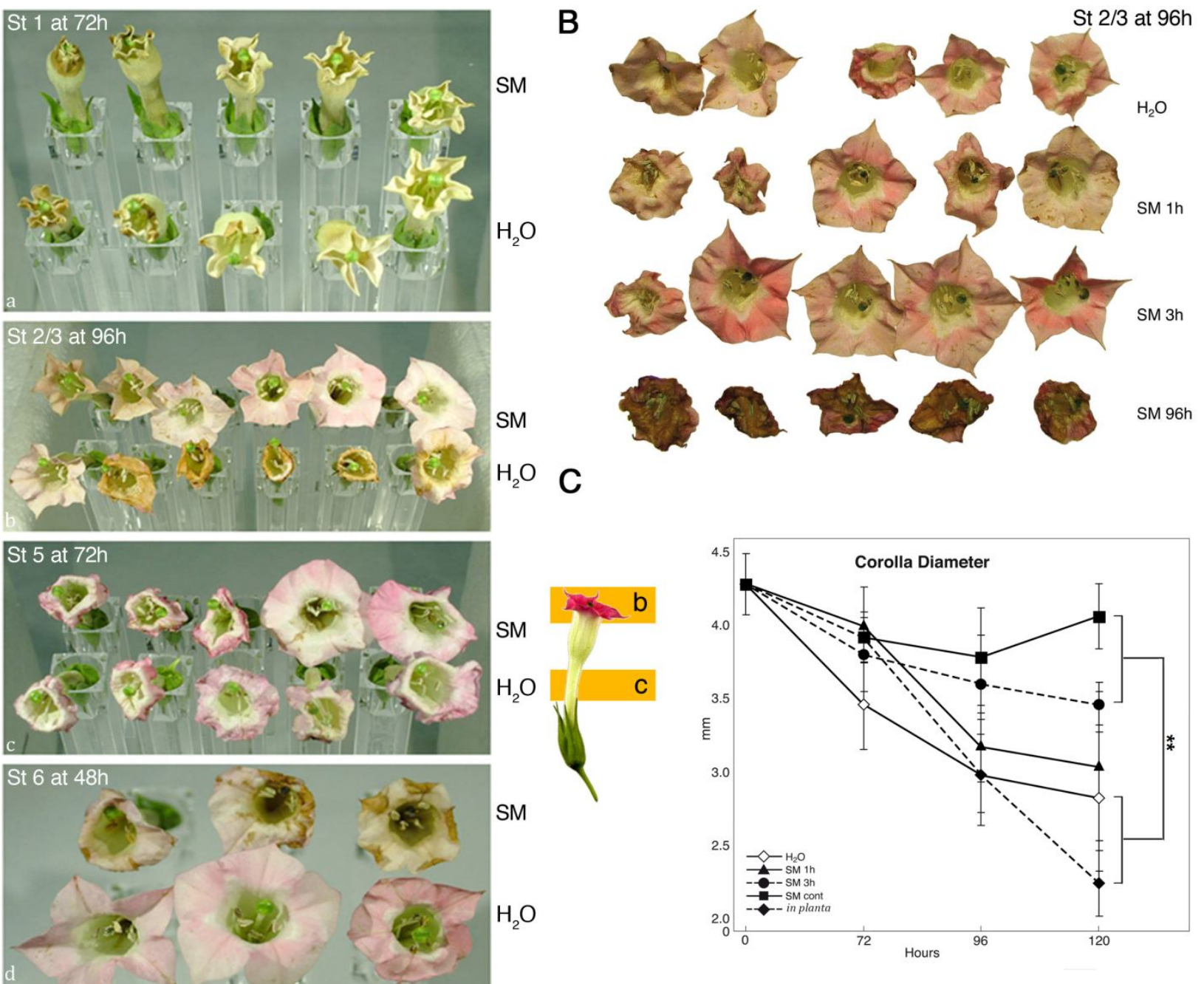

Figure 6. The effect of $25 \mathrm{mM} \mathrm{SM}$ on different parameters of corolla of $N$. tabacum flowers excised at stage 2-3. A. Fresh weight, B. Proteins, C. Antocyanins, D. Carotenoids, E. Chlorophylls $a$ and $b$. Pedicels of flowers were immersed in a SM solution for $3 \mathrm{~h}$ and then left in water until the $96^{\text {th }} \mathrm{h}$ or left continuously in water for $96 \mathrm{~h}$ as control. Symbols labeled by the same letter are not significantly different. 


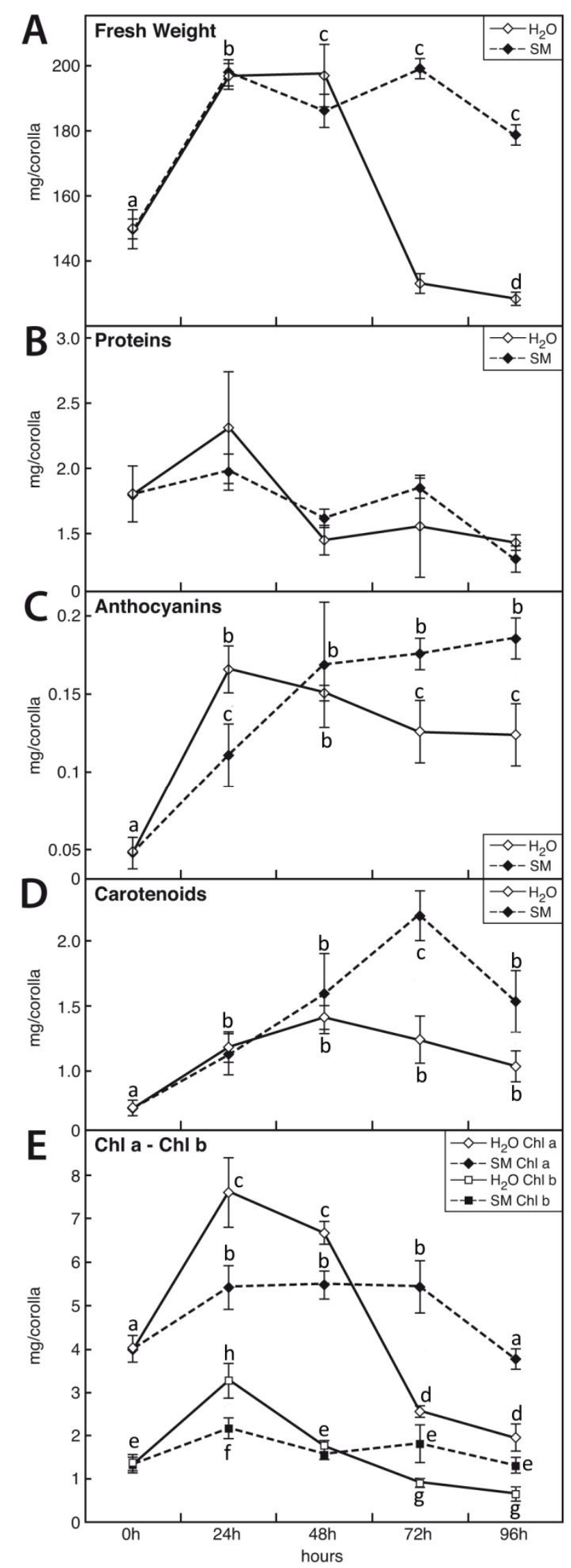


Figure 7. The effect of $25 \mathrm{mM}$ SM on DNA of corolla of $N$. tabacum flowers excised at stage 2-3. Pedicels were immersed in a SM solution for $3 \mathrm{~h}$ and then left in water up to 24, 48, 72, $96 \mathrm{~h}$ or left continuously in $\mathrm{H}_{2} \mathrm{O}$ as control for the corresponding time period. Base pairs are indicated by arrows turned right; DNA-laddering is indicated by arrows pointing left.

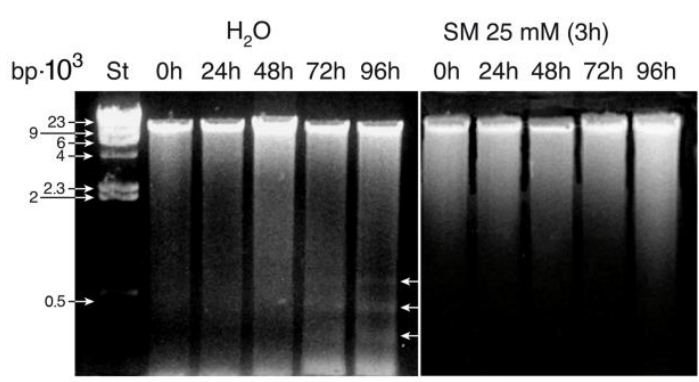

Figure 8. Effects of $25 \mathrm{mM} \mathrm{SM}$ on the distribution of TGase in the corolla of $N$. tabacum flowers excised at stage 2-3. Petals were cross-sectioned before analysis. A. Labelling with antiTGase antibody of SM-treated flower. (a) Panorama of the abaxial side of petal; (b) Detail of the epidermal cells; the arrow indicates a consistent accumulation of TGase while arrowheads indicate sides of epidermal cells with a low amount of signal. (c) Detail of the inner parenchyma cells. Arrows point to local accumulation of TGase. B. Labelling with anti-TGase antibody of untreated flower. (a) Panorama of the abaxial side of petal; (b) Detail of the epidermal cells; (c) Detail of the inner parenchyma cells. C. Measurement of fluorescence intensity in 50 x $50 \mu \mathrm{m}$ areas starting from area 1 (the epidermis) towards the inner parenchyma cells (area 5). At least 10 measures were done for each experiment. Differences between SM-treated and control samples are significant from area 3 up to $5 . *=p \leq 0.05$. 

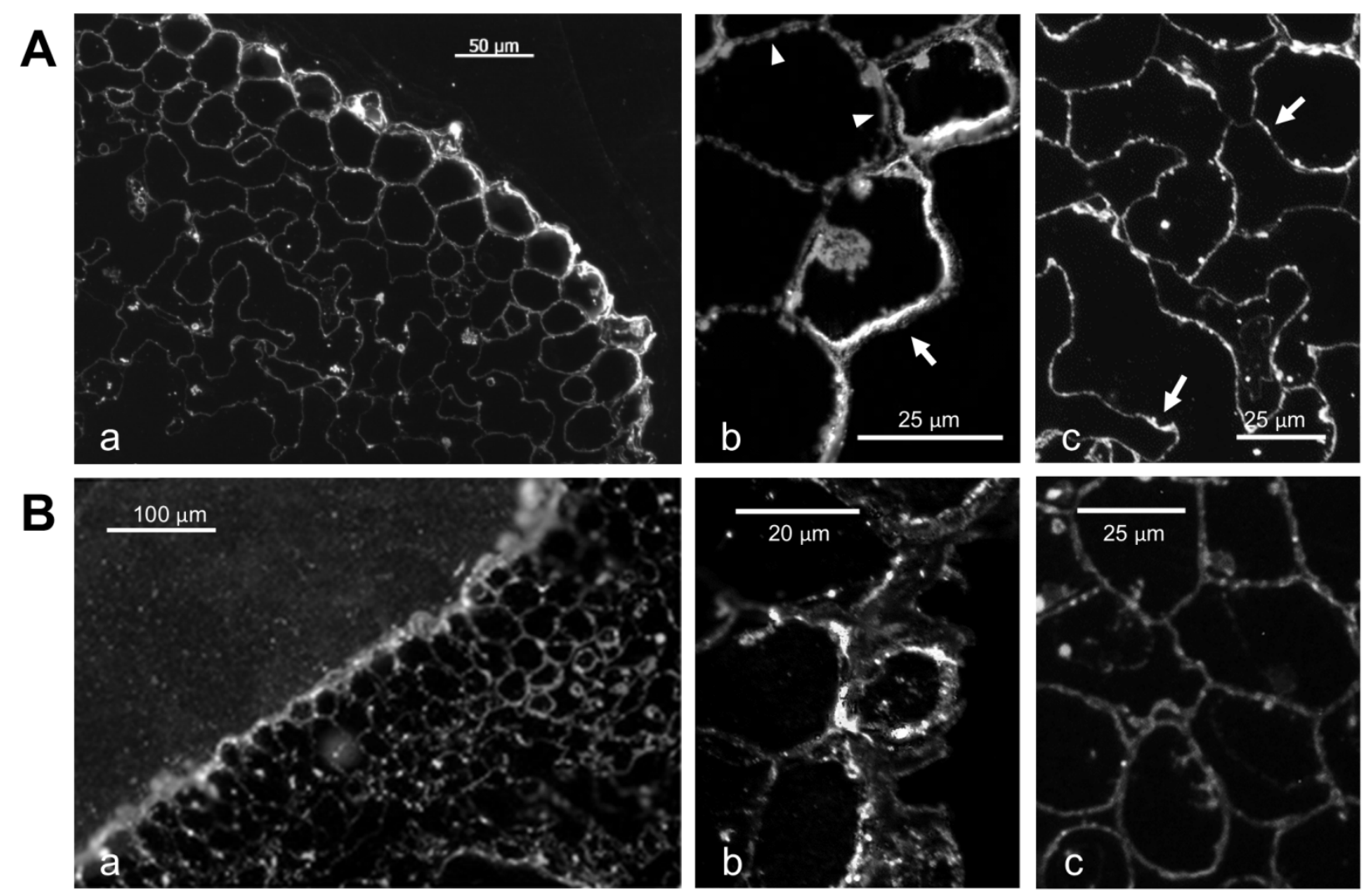

C

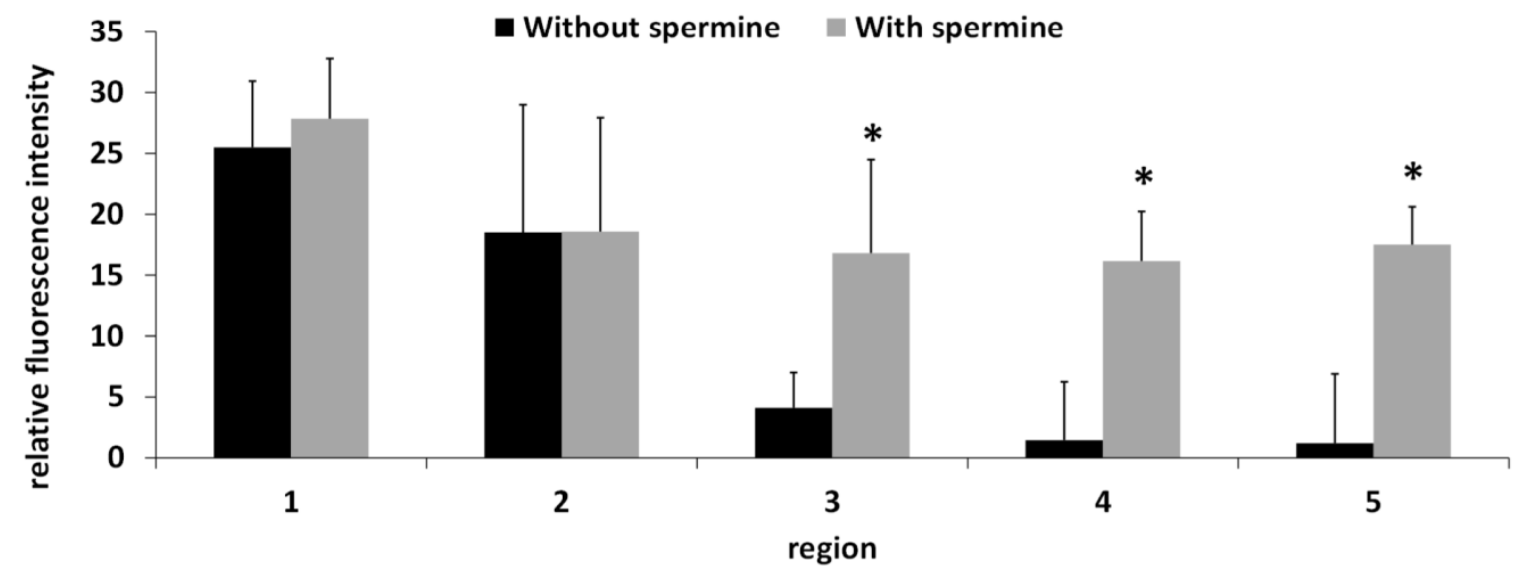

